\title{
Krešimir Mićanović: Varijacije na temu jezika i varijanata. Standardologija Dalibora Brozovića. Zagreb: Matica hrvatska, 2018., 143 str.
}

U Proslovu ovoj u ediciji Mala knjižnica Matice hrvatske objavljenoj monografiji autor se ukratko osvrnuo na proces njezina nastanka. On započinje skupom »Hrvatski jezik u XX. stoljeću «, koji su 2005. organizirali Marko Samardžija i Ivo Pranjković u nizu Matičinih znanstvenih skupova "XX. stoljeće«. Autor je ove knjige tada obrađivao standardologiju u jezikoslovnoj kroatistici te izdvojio četiri autora čiji su radovi konstitutivni za to područje u drugoj polovici 20. stoljeća - Jonke, Brozović, Katičići i Silić. Najviše su mjesta zauzele rasprave Dalibora Brozovića iz formativnoga razdoblja hrvatske standardologije. Autor je 2016. godine priredio knjigu Brozovićevih članaka objavljivanih u Telegramu (Jezik današnji 1965-1968, Zagreb: Disput) i za tu svrhu, u uvodnoj studiji, podrobno prikazao njegove općestandardološke radove, potom one u kojima se bavi varijantama i standardnom novoštokavštinom te radove o periodizaciji hrvatskoga jezičnog standarda. Ova knjiga građena je upravo na toj studiji, spoznaje su stavljene u širi jezikoslovni kontekst, ali je uzeta u obzir i Brozovićeva pozicija tijekom jezičnopolitičkih zbivanja 60-ih i 70-ih godina 20. stoljeća.

Nakon »Proslova« (str. 5-7), slijedi sedam poglavlja: »Kratak nacrt povijesti standardologije (str. 7-13), »Jezik kao dijasistem « (str. 14-32), »Standardnost slavenskih standardnih jezika (str. 33-41), »Standardni jezik i njegove varijante« (str. 42-62), »Standardna novoštokavština i hrvatski književni jezik« (str. 63-80), »Povijest hrvatskoga jezičnog standarda "(str. 81-101), »'Kopernikanski obrat': recepcija Brozovićeve standardologije (str. 102-114). Na kraju je knjige popis literature (str. 115-136), »Kazalo imena« (str. 137-140) te »Bilješka o autoru« (str. 141).

Poglavlje "Kratak nacrt povijesti standardologije« obrojčeno je nulom, što može naznačiti nekoliko stvari - ovo je poglavlje važno za potpuno razumijevanje ostalih, ali se ono možda može smatrati i artikulacijom početne faze istraživačkoga procesa. Osim što je sam nacrt nazvan kratkim, kratka je i povijest standardologije. Autor smješta njezin početak u okvire praške škole i ističe da je u razdoblju između dvaju ratova praktično bavljenje standardnim jezikom bilo smješteno u okvire jezične kulture, dok je u teorijskom smislu bilo usmjereno na oblikovanje opće teorije standardnoga jezika. U 50-im i 60-im godinama ta tema na globalnoj razini dospijeva u žarište slavističkih istraživanja, a hrvatski slavisti, ističe autor, nisu bili iznimka. Bavili su se između ostaloga definiranjem značajki i funkcija standardnih jezika, mehanizmima njihova nastanka u prednacionalnom i nacionalnom razdoblju, utvrđivanjem periodizacijskih kriterija. Brozović se u literaturi spominje kao jedno od važnih imena standardologije u svjetskim okvirima. Potkraj $60-$ ih pratimo i konstituiranje sociolingvistike kao zasebnoga područja istraživanja, čime standardni jezik postaje punopravnim objektom jezikoslovnoga interesa. 
Kao važne točke u povijesti hrvatske standardologije autor ističe pojavu časopisa Jezik, koji se deklarirano bavi kulturom hrvatskoga književnog jezika, te Jonkeova promišljanja o normi i konceptu elastične stabilnosti. Napominje se da je Jonkeov terminološki aparat bio prije svega vezan za pojam književnoga jezika, a da je standard dospio u fokus kasnije, u radovima serbokroatista, pričem su se diskusije iscrpljivale u razglabanju o pitanju je li srpskohrvatski/hrvatskosrpski jedinstven jezik ili u njemu postoje varijante. No, u tom razdoblju mlađi hrvatski filolozi Katičić i Brozović već objavljuju relevantne radove. Katičić se prije svega bavi odnosom književnoga jezika i norme, književnoga jezika i organskih govora te dijakronijske osnovice, a kao ključne njegove teze autor izdvaja onu o normiranju odnosno stvaranju književnoga jezika kao imanentno političkom činu te tezu da jedan te isti organski govor može poslužiti kao osnova dvama standardnim jezicima.

U poglavlju »Jezik kao dijasistem - standardni jezik« prikazano je kako se u 60im godinama Brozović hvata ukoštac sa svojevrsnim terminološkim odnosno koncepcijskim paradoksom u proučavanju članova slavenske jezične zajednice u genetskom i tipološkom smislu te se zauzima za strogo lučenje klasifikacije dijasistema i klasifikacije standardnih jezika. Svoje stavove gradi na argumentu da standardni jezici nisu pogodni objekti za tipološka i genetska proučavanja i predstavljaju drugu vrstu pojave u odnosu na organske govore. Autor povlači paralelu s Katičićevom tezom o trovrsnom identitetu jezika, odnosno o trima kategorijama identiteta, međusobno neovisnima. Brozović se na tu Katičićevu tezu izravno referira kasnije, u 90-im godinama, te na temelju nje piše i o trima različitim lingvistikama, međusobno neovisnima - genetskoj, tipološkoj i sociolingvističkoj. Brozović je primjerice o terminu hrvatskosrpski odnosno srpskohrvatski govorio vrlo kritično u okviru sociolingvistike, dakle kada je bila riječ o imenovanju standardnoga jezika, ali ga je, zanimljivo, smatrao najmanjim zlom kada se treba označiti dijasistem, u okviru genetske lingvistike.

U ovome se poglavlju detaljno prikazuju Brozovićevi kriteriji u definiranju idioma (s obzirom na njihovu konkretnost i dihotomiju organsko/neorgansko) te još detaljnije Brozovićevi stavovi o terminu standardni jezik i konkurentskim terminima u njemu i nama bliskim lingvističkim tradicijama. Upravo iz Brozovićeva argumentiranoga inzistiranja na terminu standardni jezik, čini se, proizlazi konačno rađanje definicije standardnoga jezika, s pravom nazivane jednom od najpoznatijih u kroatističkoj lingvistici. Genezu nam te definicije autor prikazuje u cijelosti, od 1964. do 1977.

Poseban naglasak na pojmu autonomnosti nije slučajan, jer je upravo od toga, što se tiče Brozovića, krenulo. Autonomnost je ključna ako želimo razgraničiti dijasistem i standardni jezik, odnosno pokazati da je standardni jezik neovisan o svojoj dijalektalnoj osnovici. Ta je diskusija u ovome poglavlju stavljena i u kontekst kritičkoga sagledavanja osnovne koncepcije vukovaca, odnosno njihove »dijalektološke«koncepcije pravilnoga u standardu. 
Autor postavlja i pitanje u kojoj se mjeri konzekventno zagovaranje autonomnosti standardnoga jezika može iskorištavati da se »osviješteni standardnojezični pisci/govornici 'razvlaste' svoga jezičnog standarda (...) i da se legitimiziraju (samovoljni) kodifikatorski zahvati i purističke intervencije» (str. 31). Umjesto jednoznačnoga odgovora, autor poziva na daljnju diskusiju i upućuje na Brozovićevu tezu o tome da lingvisti trebaju paziti da ne nanose štetu standardnom jeziku. Dakle, podcrtava se ograničeno shvaćanje dužnosti lingvista u kontekstu standardnoga jezika.

U poglavlju »Standardnost slavenskih standardnih jezika" polazi se od dviju Brozovićevih općeteorijskih tema: 1. hijerarhizacije i kategorizacije idioma (pri čemu Brozović inzistira na razlikovanju dijasistema i standarda po kriterijima »organskosti« i konkretnosti) i 2. sistematizacije standardnih jezika prema standardnosti.

Autor prikazuje nekoliko Brozovićevih pokušaja kvantitativne klasifikacije slavenskih standardnih jezika, pri čemu je svaka sljedeća bila nadopuna prethodne, a kanonska je inačica klasifikacije sadržavala 15 značajki/kriterija kojima se mjeri standardnost. Prva se skupina kriterija odnosi na način formiranja i funkcioniranja standardnih jezika (stupanj autonomije, elastične stabilnosti, dublete u normi, prijelazi između standarda i dijalekta, kontinuirani ili diskontinuirani razvoj). Druga se skupina odnosi na karakter osnovice standardnoga jezika i odnos prema naciji (homogena/nehomogena dijalekatska osnovica, osnovica podvrgnuta normiranju ili folklornoj stilizaciji, polivalentnost itd.). Treća skupina sadržava obilježja vezana za odnose prema drugim jezicima (prisutnost inojezičnih elemenata, purističke tendencije u jeziku itd.). U tu najrazrađeniju klasifikaciju Brozovićje unio dvije varijante »hrvatskosrpskoga «jezika - hrvatsku i srpsku.

Autor se kritički osvrnuo na činjenicu da je Brozović svih 15 obilježja odredio kao binarne opreke. Time se pri klasifikaciji uzimaju u obzir samo rubne točke kontinuuma, što je daleko od ideala preciznosti. No, napominje se da je Brozović bio pionir takva pristupa i izvan okvira hrvatskoga jezika i izvan same slavistike, što pokazuju brojni odjeci njegovih radova.

Poglavlje »Standardni jezik i njegove varijante« bavi se između ostaloga upravo odjecima, točnije silnim utjecajem koji je imala Brozovićeva knjiga Standardni jezik (1970). Autor daje detaljan popis afirmativnih prikaza te knjige u domaćim i stranim publikacijama te je smatra završnim graničnikom petogodišnje polemike koja je počela na kongresu jugoslavenskih slavista u Sarajevu u rujnu 1965.

Tamo je došlo do oštre podjele, koja nije bila isključivo obilježena polovima hrvatsko - srpsko. Naime, srpska jezikoslovka Milka Ivić iznijela je tezu da postoje dvije varijante istoga standardnog jezika s dvama kulturnim središtima, Beogradom i Zagrebom, što je naišlo na odobravanje hrvatskih filologa. Pojam varijante, ističe autor, u ovom ili onom obliku većje bio prisutan u hrvatskih i srpskih filologa, samo nije došlo do izraženoga sukoba. Dominantan je stav hrvatskih filologa (npr. Katičić, Jonke) i tada bio da standardni jezik Hrvata i Srba nije jedan i jedinstven, 
nego postoje dvije varijante. Brozović je u Sarajevu doduše izlagao o povijesti razvoja slavenske filologije, ali se uključio i u diskusiju glede varijanata. Deklarirao se za postojanje dviju, ali nikako više od dviju varijanata te iznio već prilično razrađen koncept varijante u šest točaka. Brozović smatra da je riječ o odnosu sličnom dihotomiji langue i parole. Jedinstveni standardni jezik postoji samo kao apstrakcija, dok je konkretizacija i realizacija u pismu i govoru uvijek ili gotovo uvijek varijanta. U Sarajevu, napominje autor, nije razriješeno pitanje varijanata, nije došlo ni do suglasja o tome što varijanta zapravo jest, ali se čini da je s vremenom ipak prevladalo gledište o tome da one doista postoje.

U tom se kontekstu daje osvrt na Brozovićevu ulogu u Deklaraciji, kao reakciji na postupno i sve jače nametanje srpske varijante kao državnoga jezika. Brozović je, kao i drugi potpisnici, snosio sankcije. Isključen je iz redova SKJ-a, a optužen je i da je u rubrici na stranicama Telegrama zagovarao »deklaracijske« teze. Još uvijek ne postoji suglasje o broju sastavljača Deklaracije i njihovim ulogama, kao ni o točnoj ulozi Brozovićevoj, a napominje se i kako je u hrvatskih filologa došlo do šutnje o Deklaraciji jer nije bilo oportuno o njoj pisati afirmativno sve do 90-ih.

Još je jedna polemika obilježila to razdoblje, ona oko Rječnika hrvatskosrpskog književnogjezika u izdanju Matice hrvatske i Matice srpske, prva dva sveska kojega su izdana potkraj 1967. godine. Brozović, Babić, Katičić, Ladan i drugi pišu negativne prikaze rječnika te se razvija polemika u kojoj u žarištu nije toliko leksikografija, koliko, primjećuje autor, zastupljenosti varijanata u rječniku. Spor prerasta u institucionalni sukob dviju Matica, nakon čega Matica hrvatska u potpunosti odustaje od rada na rječniku.

Zanimljivo je u tom kontekstu, zaključuje autor, da je knjiga Standardni jezik nastala s distancom u odnosu na tekuće prijepore i užarenu diskusiju. U njoj se ističe teza da hrvatskosrpski standardni jezik ne uspijeva postati nacionalnim instrumentom u internacionalnoj civilizaciji upravo zato što nisu regulirani međuvarijantski odnosi.

Poglavlje »Standardna novoštokavština i hrvatski književni jezik« bavi se odnosom dijalekatske osnovice i civilizacijsko-jezične nadgradnje u Brozovićevim radovima. Termin "standardna novoštokavština" proizašao je iz potrebe da se oslobodi konotacija koje su, prema Brozovićevu mišljenju, teško kompromitirale dvočlane nazive pokušajima da se genetskolingvistički kriteriji primijene na sociolingvistički fenomen.

Tezom da standardni jezik nikada nije samo osnovica, da ne postoji bez kulturno-civilizacijske nadgradnje, Brozović se doveo i u položaj da mora objasniti i svoj stav o nepostojanju bosanskohercegovačke (muslimanske) i crnogorske varijante. U kasnijim radovima Brozović govori o četirima konkretnim realizacijskim varijantama, ali ih ne vrednuje jednako. Autor detaljno iznosi različite koncepcije sve do 1998. te zaključuje da među kritičarima Brozovićeve koncepcije ima onih kojima je apstrakcija standardne novoštokavštine preapstraktna da bi se o njoj uopće 
govorilo kao o jezičnom sustavu, a drugima je pak onaj konkretni dio jednadžbe prekonkretan.

U poglavlju "Povijest hrvatskoga jezičnog standarda« dan je osvrt na Brozovićeva stajališta u kontekstu nesuglasja o počecima standardizacije. Struka se naime nije dogovorila o tome je li početak normativnoga oblikovanja nekoga nadregionalnog uzornog idioma i početak standardizacije, ili proces valja dijeliti na predstandardno i standardno razdoblje. Dva suprotstavljena stajališta imaju, ističe autor, i svoje metodološke reperkusije (posljedično i terminološki kaos) te se mogu svesti i na pitanje pratimo li razvoj kojega standardnog jezika od početka pismenosti kao kontinuiran proces ili ga promatramo sa suvremenih koncepcija standardnosti, polivalentnosti, institucijske općeobvezatnosti itd.

Ljudevit Jonke ističe se kao istraživač koji je prvi ozbiljnije krenuo u istraživanje povijesti književnoga jezika, pritom se fokusirajući na Tkalčevićev i Šulekov rad te prijepore oko općepoznatih onodobnih jezično-pravopisnih tema. Kao drugo veliko ime u ovom kontekstu navodi se Zlatko Vince, koji je u svojim radovima o jezičnoj povijesti obuhvatio raspon od Bašćanske ploče do 1890., s glavnim fokusom ipak na 19. stoljeću. Autor njegovu knjigu Putovima hrvatskoga književnog jezika (prvo izdanje 1978.) ocjenjuje sintezom kojoj ni danas nema premca.

Treće je veliko ime ove istraživačke teme provodni lik knjige, Dalibor Brozović. On je i sam deklarirao da su se njegovi pogledi razvijali kako je dublje ulazio u problematiku, a autor nam i ovdje daje vrijedan prikaz geneze Brozovićevih ideja glede povijesti hrvatskoga jezičnog standarda. Ona je dobrim dijelom bila obilježena oslobađanjem od zabluda prijašnjih istraživača, koje sam Brozović naziva »romantičarskima«.

Brozovićeve polazišne točke prije 1966. sažete su u nekoliko točaka: 1. razlikuju se dva predstandardizacijska procesa, hrvatski i srpski. Oni su rezultirali jednim standardnim jezikom, ali je moglo završiti i drukčije; 2. početak razvitka standardnoga jezika jest polovica 19. st., intervencijom Vuka i Gaja; 3. u skladu s tim, štokavština se prije toga treba smatrati predstandardnim idiomom.

Godina 1966. predstavlja prekretnicu. Tada Brozović deklarira da štokavski nije bio superiorna jezična materija u odnosu na kajkavski i čakavski, nego su na taj izbor utjecali izvanjezični čimbenici. Nadalje, Brozović tada ističe da hrvatski standard ne počinje s preporodom, nego priznaje važne procese koji su se događali dalje u prošlosti. Time polako otvara pitanje periodizacije prethistorije standardnoga idioma. Godine 1968. u svojoj rubrici u Telegramu važan graničnik u razvoju standarda smješta u polovicu 18. stoljeća te tvrdi da se otada ništa ključno nije mijenjalo u kontinuitetu toga jezika, osim njegova statusa.

Periodizacija hrvatske jezične povijesti u 70-im godinama 20. stoljeća postaje Brozovićeva glavna preokupacija. Autor prikazuje genezu sve do konačne varijante periodizacije, s tri predstandardna i tri standardna razdoblja hrvatskoga jezika, uz detaljniju podjelu na faze unutar pojedinih razdoblja. Zaključno su u ovome poglavlju dane i teze kojima je sam Brozović preduhitrio eventualne kritike svoje 
koncepcije, a predstavljeni su ukratko i argumenti Brozovićeva stava da pomicanje granice standarda dalje u prošlost od sredine 18. stoljeća nije opravdano.

Autor veliki Brozovićev doprinos vidi u revaloriziranju uloge narodnoga preporoda u standardizaciji i premošćivanju pretpostavljena jaza između dopreporodne i preporodne književne produkcije. Tu su tezu postupno prihvaćali i drugi eminentni hrvatski filolozi, a u poglavlju »'Kopernikanski obrat': recepcija Brozovićeve standardologije" govori se konkretno o revaloriziranju uloge Vuka Karadžića u standardizaciji hrvatskoga jezika. Ona naime ne počinje ni s njim, ni s ilircima, nego mnogo ranije. Kad se obuhvati cijela vertikala povijesti hrvatskoga književnog jezika, Karadžiću ne može pripasti uloga kakva mu je bila pripisivana. Kopernikanski obrat, očekivano, nije dobro prihvaćen od dijela srpskih filologa, a najoštrije ga je osudio Pavle Ivić, što je bilo iskrom za nekoliko polemika, u kojima stvar definitivno više nije imala isključivo lingvističke implikacije. U ovome se poglavlju procjenjuje i utjecaj Brozovićeve periodizacije na hrvatske autore, pa i na one koji početak standarda vide ranije nego on. Autor navodi osnovne točke prijepora, ali i daje svoje viđenje stvari, koje počiva na tezi da se bez uzimanja u obzir povijesnoga i političkoga konteksta, dubinskoga razumijevanja modernizacijskih procesa, ne mogu razumjeti ni procesi oblikovanja standardnoga jezika.

Zaključno možemo ustvrditi da nam ova opsegom mala, ali sadržajem krcata knjiga daje važan i vrijedan uvid u genezu nekih od najvažnijih temelja suvremenoga kroatističkog jezikoslovlja, otkriva dinamiku i mehanizme razvoja ideja, koncepata i definicija te gotovo istraživačko-biografski uvid u djelovanje osobe koja je kao lingvist, nikako političar, posvetila svoju karijeru području jezika prožetom politikom i društvenim kontekstom. Autor je posebnu težinu dao člancima nastalima od sredine 60-ih do konca 70-ih godina, ali su u obzir uzeti svi radovi određenoga područja. Time je objelodanjena teorijska sprema, upućenost i pronicljivost istraživača čiji nam primjer pokazuje da se do precizna i čista definiranja stvari može i treba doći kada se istraživač dubinski pozabavi terminološkom konfuzijom. Da je takvo što kojim slučajem prisutnije u svijesti čak i obrazovanijih u našem društvu, pa makar i samo razlikovanje dijasistema i standardnoga jezika, ne bi bilo deklariranja onoga što se o jeziku deklarirati ne može, ne bi bilo deklariranja onoga što o dijasistemu deklarirati nije potrebno, niti bi takvo što moglo biti prikazivano kao suštinski apolitično.

Kristian Novak 